\title{
The investigation of seroprevalence of Borrelia burgdorferi and Rickettsia conorii in people living in forest villages of Sinop
}

\section{Sinop'un orman köylerinde yaşayan insanlarda Borrelia burgdorferi ve Rickettsia conori seroprevalansının araştırılması}

\author{
Turabi Güineș
}

Sivas Cumhuriyet University, Vocational School of Health Services, Sivas, Turkey

Corresponding author: Turabi Güneş, Sivas Cumhuriyet University, Vocational School of Health Services, Sivas, Turkey

E-mail: turabigunes@hotmail.com

Received/Accepted: June 30, 2019 /December 31, 2019

Conflict of interest: There is not a conflict of interest.

\section{SUMMARY}

Objective: This study aimed to investigate the seroprevalence of Borrelia burgdorferi, the causative agent of Lyme disease, and Rickettsia conorii, the causative agent of Mediterranean spotted fever, in the Sinop region. Method: In 2006 and 2007, the blood serum of 184 people, living in the villages of the central district of Sinop, was obtained and stored at $80^{\circ} \mathrm{C}$ until the study. In these sera, IgG antibodies reactive to B. burgdorferi and $R$. conorii were investigated by ELISA method.

Results: Antibody positivity was found against B. burgdorferi in $36.41 \%$ and $R$. conorii in $45.10 \%$ of 184 people living in rural areas of Sinop. Reactive antibodies against $B$. burgdorferi were detected in $47.62 \%$ of 42 people with a history of redness and swelling at the contact site after the tick bite, and in $28.95 \%$ of 76 people without these symptoms $(\mathbf{p}=\mathbf{0 . 0 4 3}$, $\mathbf{O R}=\mathbf{2 . 2 3}$ ). The seropositivity to $R$. conorii was found in $57.14 \%$ and $46.05 \%$ of persons with and without these symptoms, respectively $(\mathbf{p}=$ 0.363, $O R=1.56)$. There was a statistically significant increase in seroprevalence of both $B$. burgdorferi and $R$. conorii with increasing age $(\mathbf{p}<\mathbf{0 . 0 5})$. $R$. conorii and $B$. burgdorferi co-seroprevalence were determined in $16.85 \%$ of serum samples. Since the ELISA test results in both pathogens were not repeated with confirmation tests, these findings were considered possible.

Conclusions: The findings obtained in this study revealed that Sinop and similar ecological features should be evaluated within the endemic regions for $B$. burgdorferi and $R$. conorii. It should be paying attention that infections from both pathogens may be likely to appear at these regions.

Keywords: Borrelia burgdorferi, Rickettsia conorii, lyme disease, mediterranean spotted fever, erythema migrans, tick bite
ORCID IDs of the authors: T.G. 0000-0002-8011-7844 
ÖZET

Amaç: Bu çalışmada, kene kaynaklı patojen arasındsa ön sıralarda olan Lyme hasta'lığının etkeni Borrelia burgdorferi ve Akdeniz benek ateşi etkeni olan Rickettsia conorii'nin Sinop yöresinde yaşayan insanlardaki seroprevalanslarının araştırılması amaçlanmıştır.

Yöntem: 2006-2007 yıllarında, Sinop'un merkez ilçesine bağlı köylerde yaşayan 184 kişinin kan serumu elde edilmiş ve çalışma anına kadar $-80^{\circ} \mathrm{C}^{\prime}$ de saklanmıştır. Bu serum örneklerinde ELISA yöntemiyle B. burgdorferi ve $R$. conorii'ye karşı reaktif IgG antikorları araştırılmıştır.

Bulgular: Sinop'ta kırsal kesimde yaşayan 184 kişinin \%36.41'sında B. burgdorferi'ye ve \%45,10'unda ise $R$. conorii'ye karşı antikor pozitifliği saptanmıştır. Kene tutması sonrası temas bölgesinde kızarıklığı ve şşşlik öyküsü olan 42 kișinin \%47,62'sinda, bu belirtileri olmayan 76 kişinin ise \%28.95'inde B. burgdorferi'ye karsı reaktif antikorlar tespit edilmiştir $(\mathbf{p}=\mathbf{0 , 0 4 3}, \mathbf{O R}=\mathbf{2 , 2 3})$. Bu belirtiler gösterenler ve göstermeyenlerdeki $R$. conorii'ye karșı antikor pozitifliği ise sırasıyla $\% 57,14$ ve $\% 46,05$ oranlarında elde edilmiştir $(\mathbf{p}=\mathbf{0 , 3 3 6}, \mathbf{O R}=\mathbf{1 , 5 6})$. Yaş artı̧ıyla birlikte hem B. burgdorferi, hem de $R$. conorii seroprevalansında istatistik açıdan da önemli bir artış saptanmıştır $(\mathbf{p}<\mathbf{0 , 0 5})$. Serum örneklerinin \%16,85'inde R. conorii ile B. burgdorferi ko-seropozitifliği saptanmıştır. Her iki patojen için de ELISA test sonuçları doğrulama testleri ile tekrarlanmadığından, bu bulgular olası olarak değerlendirilmiştir.

Sonuç: Bu çalışmada elde edilen bulgular, Sinop ve benzeri ekolojik özelliklere sahip yörelerin B. burgdorferi ve $R$. conorii için endemik yöreler içerisinde değerlendirilmesi gerektiğini ortaya koymuştur. Her iki patojenden kaynaklanan enfeksiyonların bu yerlerde görünmesinin muhtemel olabileceği dikkate alınmalıdır.

Anahtar sözcükler: Borrelia burgdorferi, Rickettsia conorii, Lyme hastalığ1, akdeniz benekli ateşi, Eritema Migrans, kene 1sırmas1

\section{INTRODUCTION}

Blood-fed ticks; it serves as a vector for many tick-borne pathogens that are viral, bacterial and protozoan in animals and humans. Borrelia burgdorferi, the causative agent of Lyme disease, and Rickettsia conorii, the causative agent of Mediterranean spotted fever, are among the tickborne pathogens ${ }^{1,2}$.

The main vectors of $B$. burgdorferi are ticks of the genus Ixodes, and the reservoir is usually small rodents. The genus Ixodes show a wide geographic distribution on earth and the primary vector of B. burgdorferi in Europe is I. ricinus ${ }^{(1,2)}$. The most important tick vector of $R$. conorii is the Rhipicephalus sanguineus, and the essential mammal reservoirs are dogs, rabbits and hedgehogs ${ }^{(3)}$.

Although there are many species in the genomic group $B$. burgdorferi sensu lato, in Europe, $B$. burgdorferi sensu stricto, B. afzelii, B. garinii, B. spielmanii and $B$. bavariensi cause Lyme borreliosis. The clinical picture of Lyme disease consists of 3 different stages: early local infection, early widespread infection and chronic infection. The most classic appearance of initial local infection is erythema migrans (EM), which macular or papular reddening lesions that develop between 3-30 days after tick bites. The most typical form of early diffuse infection is multiple erythema migrans (MEM), and the most characteristic clinical type of chronic disease is Acrodermatitis Chronica Atrophicans (ACA) ${ }^{2,4,5}$. Mediterranean spotted fever (MSF) caused by $R$. conorii is most common in Europe. There is a history of contact with the dog in $80 \%$ of patients with MSF. Therefore, most infections are likely to be transmitted by ticks found in dogs. Symptoms such as fever, headache and muscle pain occur 610 days after the tick bite. After the third week, maculopapular redness occurs in $95 \%$ of patients 3,6 .

In epidemiological studies on Lyme disease and MSF, indirect serological methods are often used. Indirect Immunofluorescence (IFA), Enzyme Immunoassay (EIA, ELISA) and Western blot (WB) tests are one of the methods used to determine specific antibodies in serum. Although the sensitivity and specificity of ELISA have been increased in recent years, it is recommended to confirm positive samples in Lyme-ELISA with WB. Although the sensitivity of ELISA is low during early local infection, it is $97.5 \%$ (95\% $100 \%$ ) at late stages ${ }^{4,5}$.

The many regions of Turkey, including the Black Sea region, is suitable for $R$. sanguineus and $I$. ricinus. I. ricinus is known to be abundant, especially in our coastal areas ${ }^{7}$. This study aimed to investigate the seroprevalence of B. burgdorferi and $R$. conorii in humans with a history of tick bites in villages located in the forest of Sinop and to investigate this seroprevalence in terms of sociodemographic and medical parameters. 


\section{MATERIAL AND METHODS}

\section{Study area}

In Sinop is located in the Central Black Sea region (Figure 1), rainfall is seen almost every season, the average annual rainfall is $679-1077 \mathrm{~mm}$. The average temperature is $22^{\circ} \mathrm{C}$ in summer and $7^{\circ} \mathrm{C}$ in winter. Having a mild climate, Sinop is covered with rich forests and vegetation as it always receives rainfall. This forest and vegetation contain numerous species of rodents that serve as reservoirs for tick-borne microorganisms. Besides, I. ricinus, the vectors of many microorganisms like A. phagocytophilum, B. burgdorferi and $R$. conorii, are commonly found in Sinop ?. The village settlement areas in the Sinop region are usually within the forested areas or on the edge of the forest.

\section{Collection of Blood Samples}

Between May and June in 2006 and 2007, of the 42 villages in the central district of Sinop, 14 villages were identified by cluster sampling and 900 people were contacted, and blood samples were taken from 273 of them. During the blood sampling, information such as tick bite history in the last four years, occupation and gender were recorded. After obtaining the serum of blood samples were stored at $-80^{\circ} \mathrm{C}$ until the investigation. In our previous studies, seroreactive IgG antibodies against A. phagocytophilum, Babesia microti and Tick-borne encephalitis virus (TBEV) were also investigated in these sera ${ }^{8-10}$. In this study, according to the studies previously conducted in Turkey, it was assumed that the antibody prevalence of $B$. burgdorferi and $R$. conorii would be at most $10-14 \%{ }^{11-14}$. According to 2006 data, the sample size was calculated as 182 , for the population of approximately 10.000 people living in the central villages of Sinop, at the $95 \%$ confidence interval and the $\pm 5 \%$ error. In order to investigate the prevalence of reactive IgG against $B$. burgdorferi and $R$. conorii, 184 of from 273 serum samples that we used in previous studies were included in this study according to the random sampling method. Ethics committee approval was received from Cumhuriyet University Faculty of Medicine Ethics Committee for the research $(2010-06 / 26)$.

\section{Serological Tests (ELISA)}

In the investigation of $B$. burgdorferi-IgG antibody in rural people, "Zeus Scientific, Inc. Netherland "commercial ELISA kit was used. Each 96-test ELISA test strip is in the format of 12 pieces (1x8 strip) and the microwells are coated with B. burgdorferi (strain B-131) antigen, capable of binding to $\operatorname{IgG}$ antibodies against $B$. burgdorferi sensu stricto, B. afzelii and B. garinii. Before starting the study, human serums and the contents of the ELISA kit were brought to room temperature, and the test procedure was performed. Finally, the absorbance (ABS) values of the serum samples and standard sera were determined by reading the microplates at $450 \mathrm{~nm}$ wavelength in ELISA microplate reader (Bio-Tek Instruments, Inc., Winooski, Vermont, USA). The cutoff value was found by multiplying the calibrator value by 0.25 , as indicated in the kit insert. Serums with an absorbance value above cutoff value $\mathrm{x} 1.1$ were considered positive. Serum samples positive for B. burgdorferi were subjected to RPR testing (Rapid Plasma Reagin, carbon slide) to eliminate the possibility of crossreaction between B. burgdorferi and Treponema pallidum.

$R$. conorii-IgG antibody was investigated by using a commercial ELISA kit from "Vircell microbiologist, GRANADA, SPAIN". The microwells of each 96-test ELISA test strip were coated with $R$. conorii (Moroccan strain, ATCC VR-141) antigen. Each strip was set to be used 92 test sera, two cutoffs, one positive control and one negative control, and all procedures were performed according to the commercial test procedure. Finally, the test sera, control and cutoff sera were read on the spectrophotometer at a wavelength of $450 \mathrm{~nm}$. The antibody index was calculated as indicated in the kit insert (optical density of test serum / optical density of cut of serum x 10). Serums with an antibody index of 11 or higher were considered positive.

\section{Statistics}

Chi-square test and Binary logistic regression analysis tests were used to evaluate the differences in the seroprevalence of $R$. conorii and B. burgdorferi between tick-bite history, redness after tick bite history, gender, age and occupational groups. Spearman's rank correlation tests (Spearman's rho) were used to examine the relationship between age and ELISA-IgG absorbance values of subjects. Statistical analyses were performed using licensed SPSS-23 software (SPSS, Inc., Chicago, IL) and $\mathrm{p}<0.05$ was considered statistically significant.

\section{RESULTS}

The distribution of B. burgdorferi and R. conorii seroprevalences according to different parameters in rural people in Sinop is given in Table 1. Since 3 of the 70 serum samples, which positive for $B$. burgdorferi, were also found positive in the RPR 
test, these three samples were not evaluated. As a result, antibody positivity to $B$. burgdorferi was found in $67(36.41 \%)$ and $R$. conorii in 83 $(45.10 \%)$ of 184 people living in rural areas of Sinop (Table 1).

In the distribution of $\operatorname{IgG}$ seroprevalence of $B$. burgdorferi and $R$. conorii; there was no statistically significant difference between those with and without a tick-bite history in the last four years, and between occupation group, and between genders $(\mathbf{p}>\mathbf{0 . 0 5})$.

Of 118 people with a history of tick bites, 42 $(35.59 \%)$ reported a significant redness and swelling at the contact site after the tick bite. Reactive antibodies against $B$. burgdorferi were detected in $20(47.62 \%)$ of 42 subjects with redness and swelling at the contact area after tick bites, and $22(28.95 \%)$ of 76 subjects without these symptoms after tick bites. The difference between the two groups was statistically significant $(\mathbf{p}<\mathbf{0 . 0 5})$. The risk of B. burgdorferi infection (in terms of antibody positivity) was found to be approximately 2-fold higher in subjects with redness and swelling after a tick bite than those who did not $(\mathbf{p}=\mathbf{0 . 0 4 3}, \mathbf{O R}=\mathbf{2 . 2 3}$ (CI; 1.02-4.88). Antibody positivity to $R$. conorii was observed in $57.14 \%$ and $46.05 \%$ of persons with and without redness and swelling after tick bites, respectively $(\mathrm{p}=\mathbf{0 . 3 5 6}, \mathrm{OR}=\mathbf{1 . 5 6}, \mathrm{CI} ; \mathbf{0 . 7 3 - 3 . 3 4})$.

In this study, both seroprevalences of $B$. burgdorferi and $R$. conorii were found to increase significantly with age $(\mathbf{p}<\mathbf{0 . 0 5})$ (Table $\mathbf{1})$. A significant correlation was found between the mean age and the prevalence of IgG in both $B$. burgdorferi and $R$. conorii $(\mathbf{p}<\mathbf{0 . 0 5}, \mathbf{r}: \mathbf{0 . 7 6 9}$ and 0.875, respectively). The scatter plot curve between the ELISA absorbance values ( $B$. burgdorferi or $R$. conorii) and the age of the subjects reveals the direction of this correlation (Figure 2-3). In this study, the mean age of 184 people was $44.07( \pm 18.22)$, and the median was 44. Based on the median value, both the seroprevalences of B. burgdorferi and R. conorii were higher in persons older than 44 years, according to those younger than 44 years $(\mathbf{p}<\mathbf{0 . 0 5})$. The risk of $B$. burgdorferi seropositivity was approximately 2 -fold $(\mathbf{O R}=$ 1.92, $\mathbf{C I}=\mathbf{1 . 0 5 - 3 . 5 5}$ ) in individuals older than 44 years according to people under the age of 44, while the risk of $R$. conorii antibody positivity was approximately 3 -fold $(\mathbf{O R}=\mathbf{3 . 0 3}, \mathbf{C I}=\mathbf{1 . 6 6}$ 5.55).

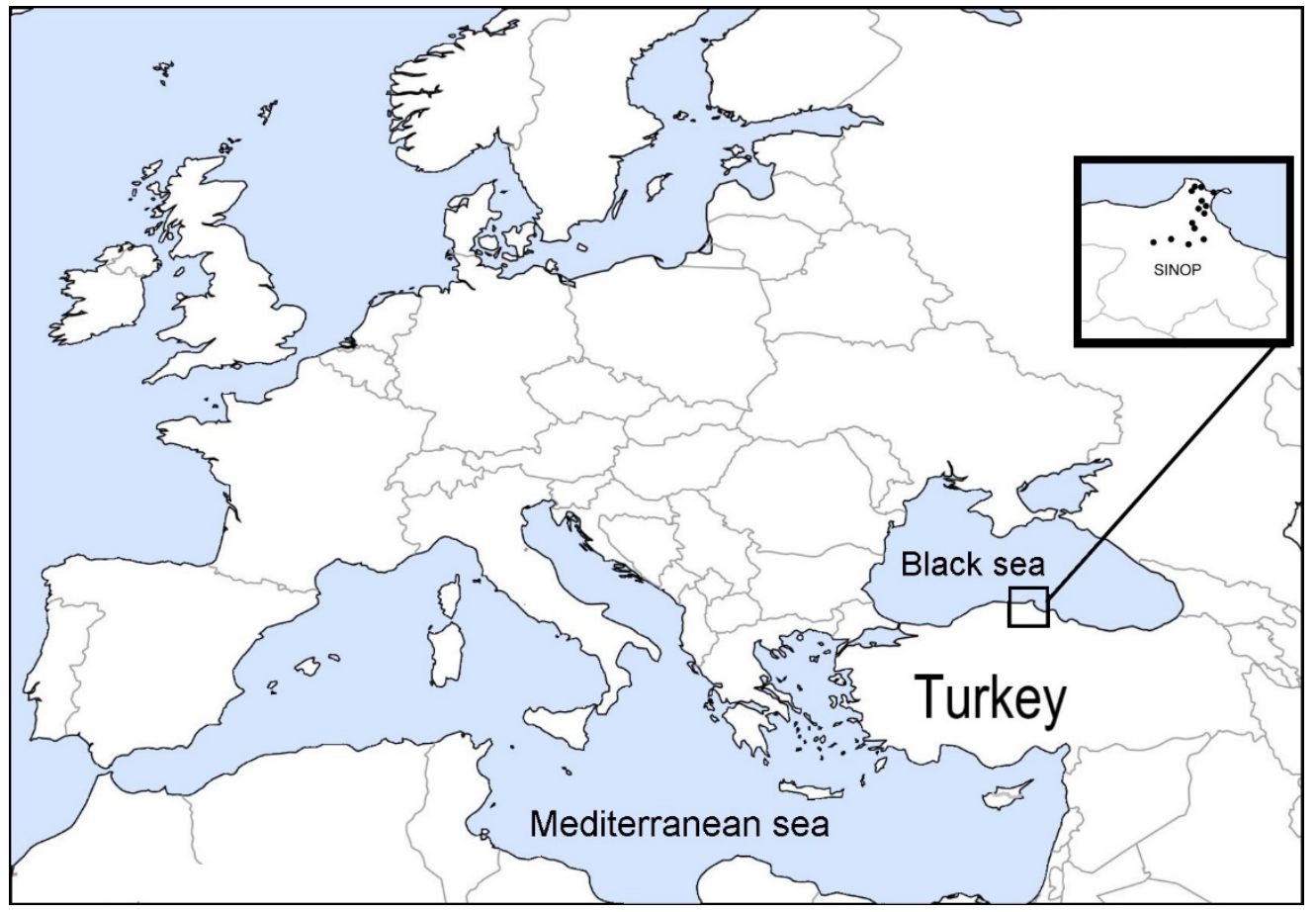

Figure 1: Forest villages of Sinop, Turkey, from which 184 persons were sampled. 
Table 1: Seroprevalence and demographic characteristics of B. burgdorferi and $R$. conorii in humans, living in rural areas of the Sinop region

\begin{tabular}{|c|c|c|c|c|c|c|c|}
\hline & & \multicolumn{3}{|c|}{ B. burgdorferi } & \multicolumn{3}{|c|}{$\underline{\text { R. conorii }}$} \\
\hline Risk factors & n & Positive (\%) & $\mathbf{X}^{2} \mathbf{P}$ & OR (CI\%95) & Positive (\%) & $\mathbf{X}^{2} \mathbf{P}$ & OR (CI\%95) \\
\hline Total & 184 & $67(36.41)$ & & & $83(45.10)$ & & \\
\hline $\begin{array}{c}\text { Gender } \\
\text { Female } \\
\text { Male* }\end{array}$ & $\begin{array}{l}90 \\
94\end{array}$ & $\begin{array}{l}33(36.67) \\
34(36.17)\end{array}$ & 0.944 & $1.02(0.56-1.86)$ & $\begin{array}{l}40(44.44)) \\
43(45.74)\end{array}$ & 0.859 & $0.95(0.53-1.69)$ \\
\hline $\begin{array}{l}\text { Tick bite } \\
\text { No* } \\
\text { Yes }\end{array}$ & $\begin{array}{l}66 \\
118\end{array}$ & $\begin{array}{l}25(37.87) \\
42(35.59)\end{array}$ & 0.757 & $0.91(0.49-1.69)$ & $\begin{array}{l}24(36.36) \\
59(50.00)\end{array}$ & 0.075 & $1.75(0.94-3.25)$ \\
\hline $\begin{array}{l}\text { Redness.Swelling } \\
\mathrm{No}^{*} \\
\text { Yes }\end{array}$ & $\begin{array}{l}76 \\
42\end{array}$ & $\begin{array}{l}22(28.95) \\
20(47.62)\end{array}$ & 0.043 & $2.23(1.02-4.88)$ & $\begin{array}{l}35(46.05) \\
24(57.14)\end{array}$ & 0.336 & $1.56(0.73-3.34)$ \\
\hline $\begin{array}{l}\text { Occupation } \\
\text { Shepherd } \\
\text { farming } \\
\text { Forest Worker* }\end{array}$ & $\begin{array}{l}35 \\
138 \\
11\end{array}$ & $\begin{array}{c}11(31.43) \\
55(39.85) \\
1(9.09)\end{array}$ & 0.099 & $\begin{array}{l}4.58(0.52-40.38 \\
6.63(0.83-53.24)\end{array}$ & $\begin{array}{l}19(54.29) \\
58(42.03) \\
6(54.55)\end{array}$ & 0.347 & $\begin{array}{l}990(0.24-3.86) \\
604(0.18-2.01)\end{array}$ \\
\hline $\begin{array}{l}\text { Age. } 44 \\
\leq 44 y^{*} \\
>44 \mathrm{y}\end{array}$ & $\begin{array}{l}96 \\
88\end{array}$ & $\begin{array}{l}28(29.16) \\
39(44.32)\end{array}$ & 0.033 & $1.92(1.05-3.55)$ & $\begin{array}{l}31(32.29) \\
52(59.09)\end{array}$ & 0.001 & $3.03(1.66-5.55)$ \\
\hline $\begin{array}{c}\text { Age groups (M) } \\
11-20(16.63)^{*} \\
21-30(26.14) \\
31-40(36.97) \\
41-50(46.08) \\
51-60(55.71) \\
61-70(64.60) \\
71-80(76.25)\end{array}$ & $\begin{array}{l}24 \\
28 \\
31 \\
36 \\
24 \\
25 \\
16\end{array}$ & $\begin{array}{l}8(33.33) \\
5(17.86) \\
8(25.81) \\
14(38.89) \\
6(25.00) \\
15(60.00) \\
11(68.75)\end{array}$ & 0.012 & $\begin{array}{l}0.44(0.12-1.57) \\
0.70(0.22-2.24) \\
1.27(0.43-3.75) \\
0.67(0.19-2.34) \\
3.00(0.93-9.63) \\
4.40(1.13-17.07)\end{array}$ & $\begin{array}{c}0(0.00) \\
8(28.57) \\
18(58.06) \\
17(47.22) \\
13(51.17) \\
16(64.00) \\
11(68.75)\end{array}$ & 0.001 & $\begin{array}{l}---(---------)^{* *} \\
3.46(1.17-10.26) \\
2.24(0.78-6.39) \\
2.96(0.94-9.31) \\
4.44(1.40-14.14) \\
5.50(1.44-20.96)\end{array}$ \\
\hline
\end{tabular}

OR: Risk ratio, CI: Confidence Interval, M: Mean, *: Reference category, **: In terms of $R$. conorii, since the seroprevalence was " 0 " in the 11-20 age group, the 21-30 age group was taken as a reference category. 


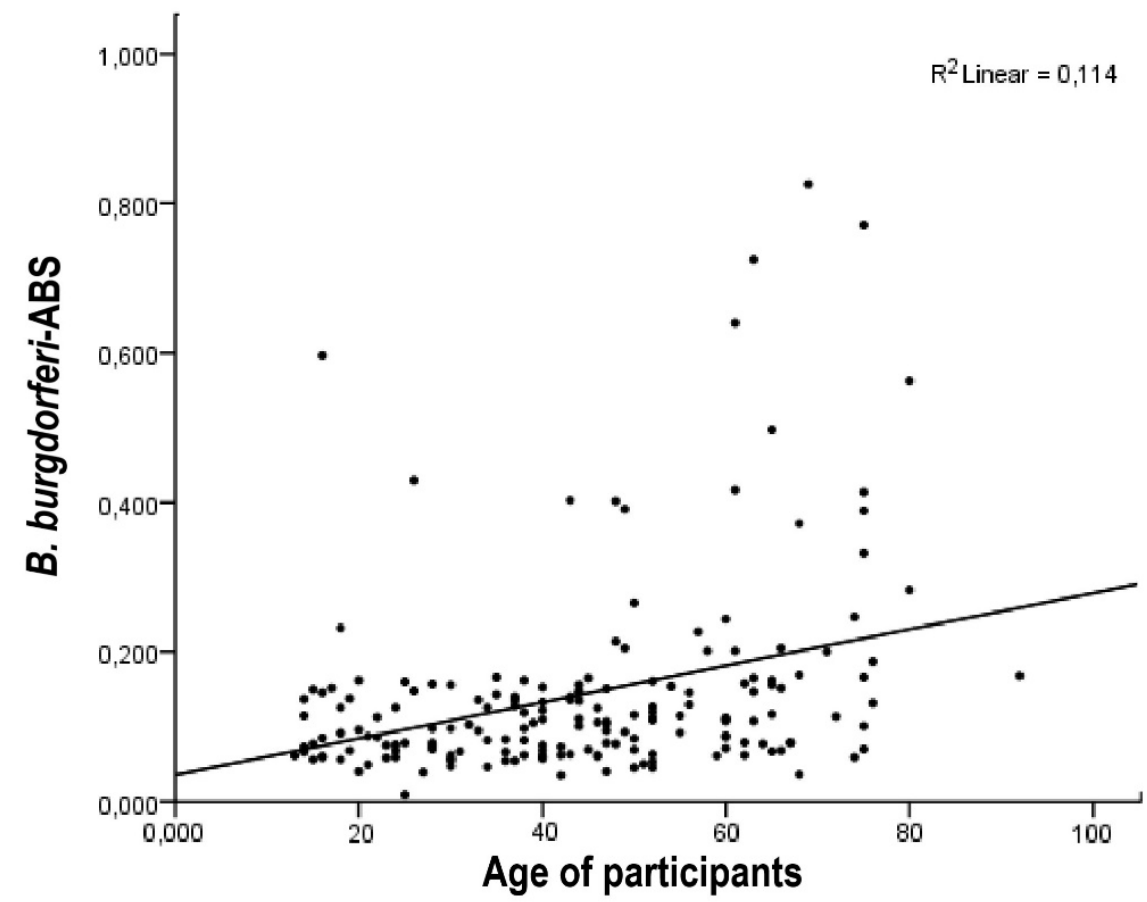

Figure 2: Scatter plot curve between ELISA absorbance values of B. burgdorferi and age of subjects

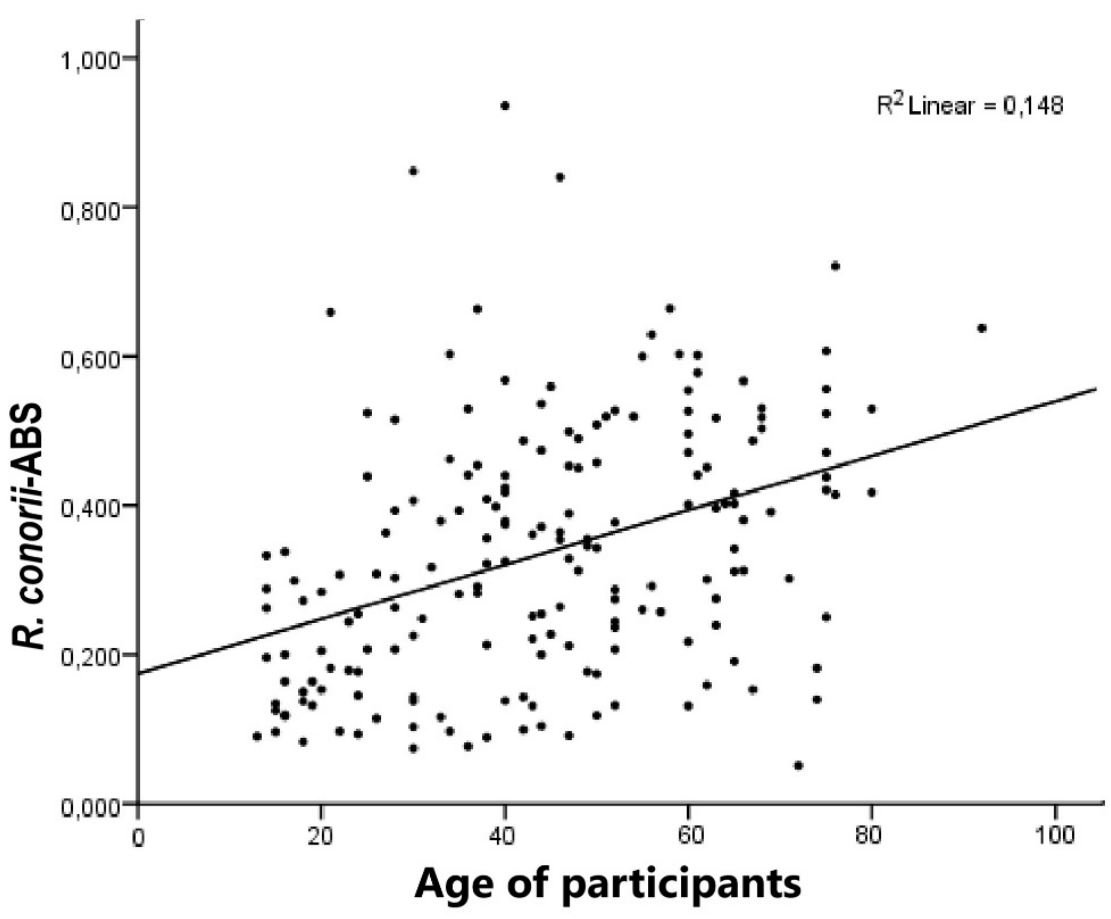

Figure 3: Scatter plot curve between ELISA absorbance values of $R$. conorii and age of subjects 
In this study, co-seropositivity of $R$. conorii and B. burgdorferi was found in $31(16.85 \%)$ of serum samples. A positive correlation was found between ELISA absorbance values of $B$. burgdorferi and $R$. conorii, and the result was statistically significant (Spearman Rho, $\mathbf{R}=$ $\mathbf{0 . 1 9 8}, \mathbf{p}=\mathbf{0 . 0 0 7}$ ). Regression was formulated as " $R$. conorii $(\mathrm{ABS})=0.303+0.174 \times$ x $B$. burgdorferi (ABS), $(\mathbf{F}=\mathbf{5 . 7 1}, \mathbf{p}=\mathbf{0 . 0 1 8})$.

In the previous studies, reactive $\operatorname{IgG}$ antibodies against $A$. phagocytophilum, B. microti and TBEV were also investigated in serum samples of this study. In our earlier studies, we found that coseroprevalence between $A$. phagocytophilum and B. burgdorferi was $3.30 \%$, and that of TBEV and B. burgdorferi was $1.5 \%$ 9,10. In the current study; in 184 serum samples, there were coseropositivity $8(4.35 \%)$ between $B$. microti and $B$ burgdorferi, 11 (5.98\%) in A. phagocytophilum and $R$. conorii, $8(4.35 \%)$ in $R$. conorii and $B$. microtii, and $3(1.63 \%)$ in TBEV and $R$. conorii.

Although the sensitivity and specificity of the $B$. burgdorferi IgG-ELISA test were very high in early generalised infection and chronic infection stages, B. burgdorferi seroprevalence detected in each parameter was evaluated as "possible results since the results were not confirmed by WesternBlot validation test.

\section{DISCUSSION}

The most important factors that determine the prevalence of tick-borne pathogens in a region are the climate of that region, the reservoir of tickborne pathogens, and the density of vector ticks. According to sociocultural and similar demographic parameters in people living in a district, the probability of contact with the tick and thus the prevalence of tick-borne pathogens may vary.

There may be differences in the incidence of MSF and Lyme disease among people living in urban and rural areas, as well as differences between different occupational groups in the same geographical area. The prevalence of antibodies to $R$. conorii in Europe and the Mediterranean coastal countries is generally between $2 \%$ and $30 \%$ in urban people and healthy blood donors ${ }^{15,16}$. However, the seroprevalence of $R$. conorii in persons in the countryside is between $10 \%$ and $60 \%{ }^{15,16}$. Sero-epidemiological findings that have been made in Turkey is a similar direction ${ }^{17}$. Lyme seroprevalence in healthy blood donors and urban population ranged from $0.48 \%$ to $19.7 \%$ $(18,19)$. Similar to $R$. conorii, the seroprevalence of $B$. burgdorferi in rural people is also high, usually ranging from $2 \%$ to $60 \%^{13,19-21}$. The prevalence of $B$. burgdorferi (36.41\%) and $R$. conorii $(45.10 \%)$ obtained in this study reveals that Sinop and similar ecological district should be evaluated in endemic areas for both pathogens.

In this study, no difference was found between the occupational groups regard both the seroprevalence of $B$. burgdorferi and $R$. conorii. The reason for this may be attributed to the fact that $90 \%$ of the people living in this region are engaged in animal husbandry. In terms of gender, according to serological studies in Turkey and other countries, conflicting results related seroprevalence of Lyme disease and MSF was reported $14,17,20-22$. In this study, both $B$. burgdorferi and $R$. conorii seroprevalence were similar levels in men and women. This result may be because men and women living in rural areas of Sinop are engaged in similar agricultural and animal husbandry activities.

In terms of people living in rural areas, the seroprevalence of tick-borne infections is generally higher in people aged 40 and over ${ }^{20,21}$. Similarly, in the present study, B. burgdorferi and $R$. conorii seroprevalence were higher in individuals over 44 years of age, according to those under 44 years. Also, a linear increase in antibody prevalence against both $B$. burgdorferi and $R$. conorii was found in parallel with the increase in age (Figure 2-3). IgG-type antibodies caused by $B$. burgdorferi and SFG-Rickettsia infections can be detected in serum for years ${ }^{23,24}$. This result may lead to a higher prevalence of $B$. burgdorferi and $R$. conorii $\operatorname{IgG}$ in higher age groups. Generally, in rural areas, with the increase in age, the duration of intraday agriculture and animal husbandry and thus the possibility of tick bite exposure may increases.

In the study, there was no difference in antibody positivity to both $B$. burgdorferi and $R$. conorii between individuals with and without a history of tick bites. The fact that a significant proportion of tick bites occur unnoticed can be an essential reason. Of the 118 people with a history of tick bites, 42 reported considerable redness and swelling at the contact site after the event. It is doubtful to determine which of these lesions are definite EM lesions. It is conceivable to think that these people's statements about redness and swelling have to do with the blood-sucking time of ticks. These lesions after tick bites can be a sign of ticks sucking blood for a sufficient time. Studies have shown that a contact time of at least 12-24 hours is required for $I$. ricinus to transfer $B$. burgdorferi to the host ${ }^{25}$. Similar contact times 
may also be necessary for $R$. conorii ${ }^{26}$. In this study, antibodies against $B$. burgdorferi were found in $47.6 \%$ of the subjects who showed signs of redness and swelling after ticks bite and $28.9 \%$ of those who did not, and the difference between the two groups was statistically significant $(\mathbf{p}=$ $\mathbf{0 , 0 4 3}, \quad O R=2,23, C I ; 1,02-4,88)$. Similarly, although there was no statistically significant difference, $R$. conorii seroprevalence was found to be higher in subjects with a history of swelling and redness after tick bites $(\mathbf{p}=\mathbf{0 , 3 3 6}, \mathbf{O R}=\mathbf{1 , 5 6}$, CI; 0,73-3,34).

The prevalence of Lyme disease in different countries of Europe varies between 0.8 and 315 per $100.000(\mathbf{2 , 1 8})$. The annual incidence of MSF cases in the Mediterranean countries is around 50 per $100.000{ }^{27}$. In Turkey, although MSF and Lyme cases were seen, there is no comprehensive documentation on the annual incidence of these pathogens ${ }^{28,29}$.

As a result, the high prevalence of antibodies against $B$. burgdorferi and $R$. conorii in humans in Sinop and similar climatic regions indicates that these people frequently encounter ticks and tickborne pathogens. Accordingly, it should be taken into account by health institutions that symptomatic $R$. conorii and B. burgdorferi infections are likely to occur.

\section{Acknowledgements}

This study was supported by the Cumhuriyet University Scientific Research Projects Commission Presidentship (CUBAP) (SHMYOOO5). During the investigation, I would like to thank the High Nurse Zübeyde Güneş for helping to collect blood from people, and thanks for Prof. Dr Ömer Poyraz and Prof. Dr Ahmet Alim for their contributions in ELISA and RPR testing.

\section{REFERENCES}

1. Shapiro ED, Gerber MA. Lyme disease. Clin Infect Dis. 2000; 31(2):533-42.

2. Stanek G, Wormser GP, Gray J, Strle F. Lyme borreliosis. Lancet (London, England). 2012;379(9814):461-73.

3. Parola P, Paddock CD, Socolovschi C, Labruna MB, Mediannikov O, Kernif T, et al. Update on tick-borne rickettsioses around the world: a geographic approach. Clin Microbiol Rev. 2013;26(4):657-702.

4. Carriveau A, Poole H, Thomas A. Lyme Disease. Nurs Clin North Am. 2019;54(2):261-75.

5. Wilske B, Fingerle V, Schulte-Spechtel U.
Microbiological and serological diagnosis of Lyme borreliosis. FEMS Immunol Med Microbiol. 2007;49(1):13-21.

6. Buckingham SC. Tick-borne infections in children: epidemiology, clinical manifestations, and optimal management strategies. Paediatr Drugs. 2005;7(3):16376.

7. Gunes T, Kaya S, Poyraz O, Engin A. The prevalence of Borrelia burgdorferi sensu lato in Ixodes ricinus ticks in the Sinop region of Turkey. Turkish J Vet Anim Sci. 2007;31(3):153-158.

8. Poyraz O, Gunes T. [Seroprevalance of Babesia microti in humans living in rural areas of the Sinop region]. Turkish Society for Parasitology. 2010;34(2):81-85.

9. Gunes T, Poyraz O, Atas M, Turgut NH. The seroprevalence of Anaplasma phagocytophilum in humans from two different climatic regions of Turkey and its co-seroprevalence rate with Borrelia burgdorferi. Turkish J Med Sci. 2011;41(5):903-908.

10. Gunes T, Poyraz O, Atas M, Alim A. Seroprevalence of tick-borne encephalitis virus (TBEV) among the residents of rural areas in Sinop, central black-sea region, Turkey. Mikrobiyol Bul. 2010;44(4):58591.

11. Vural T, Ergin C, Sayin F. Investigation of Rickettsia conorii antibodies in the Antalya area. Infection. 1998;26(3):170-2.

12. Kuloglu F, Rolain JM, Aydoslu B, Akata F, Tugrul M, Raoult D. Prospective evaluation of rickettsioses in the Trakya (European) region of Turkey and atypic presentations of Rickettsia conorii. Ann N Y Acad Sci. 2006;1078(1):173-5.

13. Kaya AD, Parlak AH, Ozturk CE, Behcet M. Seroprevalence of Borrelia burgdorferi infection among forestry workers and farmers in Duzce, north-western Turkey. New Microbiol. 2008;31(2):203-9.

14. Rad AY, Hekimler K. Seroepidemiologic Study On Lyme Borreliosis In Isparta Region In Turkey. Hacettepe J Biol Chem. 2007;35(2):105-9.

15. Punda-Polić V, Klismanić Z, Capkun V. Prevalence of antibodies to spotted fever group rickettsiae in the region of Split (southern Croatia). Eur J Epidemiol. 
2003;18(5):451-5.

16. Daniel SA, Manika K, Arvanmdou M, Antoniadis A. Prevalence of Rickettsia conorii and Rickettsia typhi infections in the population of northern Greece. Am J Trop Med Hyg. 2002 Jan 1;66(1):76-9.

17. Gunes T, Poyraz O, Ataş M, Turgut NH. The seroprevalence of Rickettsia conorii in humans living in villages of Tokat Province in Turkey, where Crimean-Congo hemorrhagic fever virus is endemic, and epidemiological similarities of both infectious agents. Turkish J Med Sci. 2012;42(3):441-48.

18. Hvidsten D, Mortensen L, Straume B, Arsenovic MG, Pedersen A-B, Lyngås G, et al. Blood donor Borrelia burgdorferi sensu lato seroprevalence and history of tick bites at a northern limit of the vector distribution. APMIS. 2017;125(8):717-24.

19. Hristea A, Hristescu S, Ciufecu C, Vasile A. Seroprevalence of Borrelia burgdorferi in Romania. Eur $\mathrm{J}$ Epidemiol. 2001;17(9):891-6.

20. Zając V, Pinkas J, Wójcik-Fatla A, Dutkiewicz J, Owoc A, Bojar I. Prevalence of serological response to Borrelia burgdorferi in farmers from eastern and central Poland. Eur J Clin Microbiol Infect Dis [Internet]. 2017;36(3):437-46.

21. Akar N. Seroprevalence of hantavirus and Borrelia burgdorferi in Düzce (Turkey) forest villages and the relationship with sociodemographic features. Turkish J Med Sci. 2019;49(2):483-9.

22. Alakus I, Sahin Horasan E, Kurt AO, Evik G, Ersoz G, Aslan G, et al. Seroprevalence of rickettsioses among healthy individuals in Mersin province, Turkey Turk J Public
Health. 2016;14(3):128-134.

23. Kalish RA, McHugh G, Granquist J, Shea B, Ruthazer R, Steere AC. Persistence of immunoglobulin $\mathrm{M}$ or immunoglobulin $\mathrm{G}$ antibody responses to Borrelia burgdorferi 10-20 years after active Lyme disease. Clin Infect Dis. 2001;33(6):780-5.

24. Mansueto S, Vitale $G$, Bentivegna $M$, Tringali G, Di Leo R. Persistence of antibodies to Rickettsia conorii after an acute attack of boutonneuse fever. J Infect Dis. 1985; 151(2):377.

25. Sood SK, Salzman MB, Johnson BJ, Happ CM, Feig K, Carmody L, et al. Duration of tick attachment as a predictor of the risk of Lyme disease in an area in which Lyme disease is endemic. $J$ Infect Dis. 1997;175(4):996-9.

26. Saraiva DG, Soares HS, Soares JF, Labruna MB. Feeding Period Required by Amblyomma aureolatum Ticks for Transmission of Rickettsia rickettsii to Vertebrate Hosts. Emerg Infect Dis. 2014;20(9):1504-10.

27. Brouqui P, Parola P, Fournier PE, Raoult D. Spotted fever rickettsioses in southern and eastern Europe. FEMS Immunol Med Microbiol. 2007;49(1):2-12.

28. Karagun E, Ozcan Y. Early Stage Lyme Disease Diagnosis: Two Case Reports. Turkiye Klin J Dermatology. 2018;29(1):36-9.

29. Kuloglu F, Rolain JM, Fournier PE, Akata F, Tugrul M, Raoult D. First isolation of Rickettsia conorii from humans in the Trakya (European) region of Turkey. Eur J Clin Microbiol Infect Dis. 2004;23(8):609-14. 